\title{
The Right to Discriminate
}

\author{
RUSSELL SANDBERG ${ }^{1}$ \\ Lecturer, Cardiff Law School \\ Research Associate, Centre for Law and Religion, Cardiff University
}

\begin{abstract}
The first decade of the 21st century has witnessed a number of controversies surrounding the interaction between law and religion in the United Kingdom. In particular, tensions have emerged between laws protecting religious freedom and those which prohibit discrimination on grounds of sexual orientation. In particular, Parliament has repeatedly examined the scope and ambit of exceptions afforded to religious groups which allow them to discriminate on grounds of sexual orientation when specific conditions are met. And these exceptions have reportedly led to tensions within both the Blair and Brown cabinets and rebukes from the Vatican and the European Commission, criticising the exceptions for being too narrow and too broad respectively. The exceptions have also been challenged by way of judicial review, have been applied or commented upon in a number of high-profile cases and have attracted comment in the print and broadcast media. A number of employees have brought claims asserting that new legal requirements promoting equality on grounds of sexual orientation are incompatible with their religious beliefs. This article seeks to explore the legal changes that have occurred in the first decade of the 21st century affecting religion and sexual orientation with particular reference to how courts and tribunals have dealt with clashes between the two. It discusses the extent to which English law allows religious groups and individuals to follow their own beliefs regarding human sexuality.
\end{abstract}

\section{INTRODUCTION}

Looking at the broad historical canvas, it may be observed that religion and sexual orientation have shared similar legal journeys. ${ }^{2}$ At first the law embodied discrimination against people of certain religions and sexual orientations.

1 This article is based upon the text of a public lecture delivered on 3 June 2009 as part of the Ecclesiastical Law Society's London Lecture Series and papers delivered at a workshop on 'Religion, Discrimination and Accommodation' funded by the AHRC / ESRC Religion \& Society Programme in Newcastle on 5 June 2008, a seminar on 'Role of Religion and Belief in a "Secular" Society' organised by the Equality and Human Rights Commission in Lancaster on 28 April 2009 and a meeting of the Interfaith Legal Advisers Network convened by Cardiff University's Centre for Law and Religion at Lambeth Palace, London on 1 March 2010. I am grateful to the organisers and attendees of these events whose comments have undoubtedly improved the quality of the article. The feedback of my colleagues at the Centre for Law and Religion and students on the LLM in Canon Law at Cardiff has also been invaluable.

2 For an examination of the historical development of laws protecting sexual orientation see chapter 1 of S Cretney, Same Sex Relationships: from odious crime to 'gay marriage' (Oxford, 2006). For examinations of the historical development of laws protecting religion see chapter 1 of J Rivers, The Law of Organized Religions (Oxford, 2010) and chapter 2 of R Sandberg, Law and Religion (Cambridge, 2011). 
English law favoured the Church of England ${ }^{3}$ and heterosexuality to the extent that other forms of religion and sexual orientation were actively disadvantaged. Over time, however, much of this favouritism came to an end. ${ }^{4}$ Many discriminatory laws were removed and the legal picture became characterised by nondiscrimination. Other religious groups and homosexuality became tolerated. This toleration was achieved on an ad hoc and piecemeal basis and came much later in relation to sexual orientation than religion. ${ }^{5}$ However, it may be argued that the legal position has changed once again in the 21st century. English law now actively promotes anti-discrimination.

It may be said that the legislation of the last decade or so has resulted in a 'new' law on religion and a 'new' law on sexual orientation. ${ }^{6}$ There have been four important legal developments. First, the Human Rights Act 1998, in force from October 2000, 'brought rights home' by largely incorporating the European Convention on Human Rights into English law, including the Article 8 right to respect for private and family life and the Article 9 right to freedom of thought, conscience and religion.7 Second, the Civil Partnership Act 2004 created a new legally recognised human relationship based on sexual orientation that excluded religion: the law prohibited the use of a religious service during a civil partnership ceremony and stipulated that a civil partnership could not be registered on religious premises. Third, there were developments in criminal law: stirring up hatred on grounds of religion or belief and sexual orientation became specifically outlawed. ${ }^{8}$ Fourth, there were developments in discrimination law: discrimination on grounds of religion or belief and sexual orientation was expressly prohibited in England and Wales in relation to employment ${ }^{9}$ and goods and services. ${ }^{10}$

3 With the exception of the period of Mary I's reign when papal authority was restored (1553-1558) and the commonwealth period (1648-1660). See M Hill and R Sandberg, 'Is nothing sacred? Clashing symbols in a secular world' [2007] Public Law 488, p 489.

4 However, it may be argued that aspects of this favouritism remain today: for example, in relation to concerns about the presence of bishops in the House of Lords and why civil partnerships are not considered to be gay marriages. A textbook example of this favouritism is the law on marriage which continues to see the Church of England and heterosexual unions as the norm.

It was only in 1967 that the criminal offence prohibiting homosexual conduct between consenting male adults was repealed in England and Wales by the Sexual Offences Act 1967. Repeal in Scotland came later and in Northern Ireland much later still. See Cretney, Same Sex Relationships, chapter 1.

6 For further analysis of the 'new' law regulating religion and its significance see Sandberg, Law and Religion.

7 Other rights are also of importance. Art 12 provides the right to marry and Art 14 provides that the enjoyment of convention rights shall be secured without discrimination.

8 Public Order Act 1986 part 3A, as added by the Racial and Religious Hatred Act 2006; as amended by the Criminal Justice and Immigration Act 2008.

9 Employment Equality (Religion or Belief) Regulations 2003; Employment Equality (Sexual Orientation) Regulations. Prior to 2003, discrimination law covered only race and sex (Race Relations Act 1976; Sex Discrimination Act 1975) as discussed below. 
These developments are ongoing. The Equality Act 2010 has recently consolidated the substantive law relating to religious and sexual orientation discrimination and the exceptions that exist for religious groups. ${ }^{11}$ Section 202 of the Act made provisions to remove the prohibition on registering civil partnerships on religious premises but this is not yet in force. Moreover, these legislative developments have led to a great deal of litigation concerning the ambit of these new laws and what should happen when provisions protecting sexual orientation clash with those protecting religion or belief.

Collectively these developments constitute a significant shift from nondiscrimination to anti-discrimination, from passive tolerance to the active promotion of religious freedom and sexual autonomy as positive legal rights. The legal framework today is very different from ten years ago. The law now goes notably further than the ad hoc and piecemeal protection which existed in the 2oth century. This article seeks to tell the story of how the law has changed and what impact this has had upon the right to discriminate: to what extent does English law allow religious groups and individuals to follow their own beliefs regarding human sexuality? ${ }^{12}$

\section{THE NEW LAW}

The latter half of the 2oth century saw a number of significant legal developments which served as important precursors to the four legal developments explored in this article. However, generally, these developments did not go as far as the laws of the 21st century. The 2oth century saw the positive conferral of progressive but specific rights by Acts of Parliament. In relation to religion, for example, ${ }^{13}$ conscientious objections to military service, oath taking and abortion were recognised ${ }^{14}$ and specific exceptions were granted to Sikhs from laws requiring safety hats on a building sites and requiring protective headgear when motorcycling. ${ }^{15}$ In relation to sexual orientation, "statutory discrimination against same-sex couples was remedied in a number of discrete areas': ${ }^{16}$ by

11 There is a debate as to whether the term 'exception 'or 'exemption' should be used. This article follows the practice of the Equality Act 2010 which refers to 'exceptions'. This can be contrasted with much of the Parliamentary debates where the use of the term 'exemption' was commonplace.

12 There are, of course, several other dimensions to this debate: it is possible to explore the content of the beliefs held, whether they should be held and their theological basis. However, those issues are beyond the scope of this article.

13 See R Sandberg and N Doe, 'Religious Exemptions in Discrimination Law', (2007) 66(2) Cambridge Law Journal 302 at 302-303.

14 Military Service Act 1916, s 2; Promissory Oaths Act 1868; Oaths Act 1978; Abortion Act 1967, s 4.

15 Employment Act 1989, s 11; Motorcycle Crash Helmets Religious Exemption Act 1976, now see Road Traffic Act 1988, s 16 .

16 N Gray and D Brazil, Blackstone's Guide to the Civil Partnership Act 2004 (Oxford, 2005), p 2. 
the 21st century, the letter of the law was modified to allow same-sex couples to apply for adoption orders and for occupation orders, for example. ${ }^{17}$

In relation to these specific (and often hard fought for) dispensations, some laws were enacted that began to give more general protection. From the 1950 s onwards international human rights treaties and the ideals they embodied began to influence the law. Articles of the European Convention on Human Rights, including Articles 8 and 9, were regarded as an aid to interpretation and English courts sought to ensure that their decisions conformed to the Convention. This was particularly true in relation to Article 8: Strasbourg decisions relying upon Articles 8 and 14 held several pieces of UK legislation discriminating against homosexuals to be unlawful..$^{18}$ Moreover, laws prohibiting discrimination on the grounds of race and sex provided some limited overlapping protection. ${ }^{19}$ Religious claims attempted to 'fit' within claims of racial discrimination whilst claims concerning sexual orientation tried to 'fit' their complaints under sex discrimination legislation. ${ }^{20}$ Most notably, Sikhs ${ }^{21}$ and Jews $^{22}$ were protected as races under Race Relations Act $1976^{23}$ and some religious practices were protected as ethnic practices. ${ }^{24}$ In contrast, attempts to 'fit' sexual orientation discrimination claims into sex discrimination claims generally failed: ${ }^{25}$ most notably the House of Lords in Macdonald $v$ Ministry of Defence and Pearce $v$ Governing Body of Mayfield Secondary School ${ }^{26}$ held that term 'sex' within section 1 of the 1975 Act related to gender and not sexual orientation and so abuse directed at an individual's sexual orientation fell outside the 1975 Act. The Sex Discrimination Act 1975 did, however, provide some rights for religious bodies since it included a specific exception for 'organised religions' permitting, for instance, the existence of an all-male priesthood. ${ }^{27}$ This began the practice under English law to provide exceptions for religious groups

In general, therefore, whilst there were important developments in the 2oth century, these are now mostly notable for the manner in which they paved the

Adoption and Children Act 2002; Domestic Violence, Crime and Victims Act 2004.

Dudgeon v United Kingdom (1981) 4 EHRR 149; Smith and another v United Kingdom (2000) ECHR $33985 / 96$.

Race Relations Act 1976; Sex Discrimination Act 1975.

N De Marco, Blackstone's Guide to the Employment Equality Regulations 2003 (Oxford, 2004) p 5. Mandla v Dowell Lee [1983] 2 AC 548.

Seide $v$ Gillette Industries Limited [1980] IRLR 427.

However, most religious groups not protected. The Act did not cover Muslims (JH Walker Limited $v$ Hussain and Others [1996] ICR 291) or Rastafarians, for example (Crown Suppliers (Property Services Agency) Limited v Dawkins [1993] ICR 517).

For example, in JH Walker Limited $v$ Hussain, it was held that a ban on holidays during festival of Eid constituted indirect discrimination against Asians.

De Marco, Blackstone's Guide to the Employment Equality Regulations 2003, p 7.

[2003] UKHL 34.

Section 19. The Employment Equality (Sex Discrimination) Regulations 2005 amended s 19. It has also repealed s 6 of the Priests (Ordination of Women) Measure 1993, which buttressed s 19 in the case of the Church of England. The exception is now to be found in Schedule 9 of the Equality Act 2010, as discussed below. 
way for the wider-ranging developments of the 21st century. The remainder of this article will examine the four components of the new law in turn: the Human Rights Act 1998, the Civil Partnership Act 2004, the criminal offences of stirring up hatred on grounds of religion and sexual orientation and the prohibition of discrimination on those two grounds.

\section{THE HUMAN RIGHTS ACT 1998}

In addition to making it unlawful for public authorities to act in a way which is incompatible with a Convention right, ${ }^{28}$ the Human Rights Act required very different approaches to interpretation. ${ }^{29}$ These required judges 'not to cast around in the European Human Rights Reports like black-letter lawyers seeking clues' but rather to 'to draw out the broad principles which animate the Convention'. ${ }^{30}$ The Act ushered in a new rights-driven approach promoting religious freedom and the right to a private life as universal human rights. ${ }^{31}$ Moreover, as part of this new legal culture, it has become normal to speak about the balancing of these rights as a means to resolve or at least minimise the tensions between them. However, although the Human Rights Act has brought about a profound cultural change by introducing a rights-focused vocabulary, it would appear that the Human Rights Act 1998 has had a greater effect in relation to sexual orientation than religion. ${ }^{32}$

\section{The effect upon religion}

In relation to religion, the incorporation of Article 9 into domestic law has led to a number of high-profile cases. ${ }^{33}$ However, analysis of this case law suggests that domestic courts are applying Article 9 somewhat restrictively. The statement

Section $6(1)$. A 'public authority' is defined as 'any person certain of whose functions are of a public nature' (s 6(3)) and thus may include religious groups and entities within religious organisations. On which see Parochial Church Council of the Parish of Aston Cantlow and Wilmcote with Billesley, Warwickshire $v$ Wallbank and another [2003] UKHL 37.

29 The Human Rights Act requires courts to interpret United Kingdom legislation so far as is possible in a manner compatible with the rights outlined in the ECHR and in so doing they must take into account - though not necessarily follow - the decisions of the European Court at Strasbourg. Lord Slynn in $R$ (Alconbury Developments Ltd) $v$ Secretary of State for the Environment, Transport and the Regions [2001] UKHL 23, para 26 has suggested that courts should only feel under an obligation to follow Strasbourg case law where there is a 'clear and constant jurisprudence'.

As Morritt V-C put it in Aston Cantlow [2001] 3 All ER 393 at para 44. This Court of Appeal judgment was later overturned by the House of Lords: [2003] UKHL 37.

31 As Cretney puts it, "The enactment of the Human Rights Act 1998 encouraged the view that "discrimination" of any kind was unacceptable (even though that is not actually what the Act or the convention says)': Cretney, Same Sex Relationships, p 13.

32 The Human Rights Act 1998 is one of the major catalysts of the increase of focus on religious rights which may be referred to as the 'juridification' of religion. See, further, Sandberg, Law and Religion, chapter 10 .

On which see ibid, chapter 5 . 
first made in Begum ${ }^{34}$ that 'interference is not easily established' has been used repeatedly to hold that there was no interference with the right to manifest religion; ${ }^{35}$ and in the rare cases where the court have held that there has been an interference with Article 9(1) then the courts have held that interference to be justified under Article 9(2). ${ }^{36}$ The lone successful case on religious dress in schools, $R$ (on the application of Watkins-Singh) $v$ The Governing Body of Aberdare Girls' High School37, argued under discrimination laws, illustrates the extent to which litigants will now argue anything but Article 9. ${ }^{38}$

\section{The effect upon sexual orientation}

In contrast, it has been asserted that the Human Rights Act 1998 'heralded both a statutory and a judicial change towards discrimination against same-sex couples'. ${ }^{39}$ Although some commentators have noted that the impact of the Human Rights Act 1998 has been less in family law than in other areas of law $^{40}$ (because the ECHR protects individual rather than family rights),$^{41}$ it is clear that the Act has had a greater impact upon the protection of sexual orientation rather than religion. Although bold judicial interpretation in the area of family law is by no means novel, ${ }^{42}$ a number of $\operatorname{cases}^{43}$ show the 'the increasing

$34 R$ (on the application of Begum) $v$ Headteacher and Governors of Denbigh High School [2006] UKHL 15.

35 Eg in $R$ (on the application of X) v Y School [2007] EWHC 298 (Admin); $R$ (on the Application of Playfoot (A Child) v Millais School Governing Body [2007] EWHC 1698 (Admin).

36 Eg Rv Secretary of State for Education and Employment and others ex parte Williamson [2005] UKHL 15; $R$ (on the Application of Swami Suryananda) $v$ Welsh Ministers [2007] EWHC 1736 (Admin).

37 [2008] EWHC 1865 (Admin).

38 R Sandberg, 'The changing position of religious minorities in English law: the legacy of Begum', in R Grillo et al (eds) Legal Practice and Cultural Diversity (Aldershot, 2009), p 267; I Leigh, 'Recent developments in religious liberty', (2009) 11 Ecc LJ 65.

39 Gray and Brazil, Blackstone's Guide to the Civil Partnership Act 2004, p 2. Whether the Act preceded or followed a similar moral shift is an open question.

40 J Herring, Family Law (third edition, Pearson, 2007) p 31, citing Harris-Short's suggestion that family law judges have taken a 'minimalist' approach to the use of the Act given the long suspicion of rights among family lawyers: S Harris-Short, 'Family law and the Human Rights Act 1998: judicial restraint or revolution', (2005) 17 Child and Family Law Quarterly 329.

41 See G Douglas, An Introduction to Family Law (second edition, Oxford, 2004), pp 14-15.

42 Crabbe gives the additional example of the definition of 'family' in section 12 of the Increase of Rent and Mortgage Interest (Restrictions) Act 1920: although in Gammans v Ekins [1950] 2 KB 328 it was held that it would be 'an abuse of the English language' to hold that a childless couple masquerading as husband and wife constituted a 'family'; over twenty years later, in Dyson Holdings Ltd v Fox [1976] QB 503, childless cohabiters were held to constitute a family: Lord Denning MR held that the decision in Gammans v Ekins could 'no longer be supported' since 'owing to the lapse of time, and the change in social conditions, the previous decision is not in accord with modern thinking' and James LJ warned against applying 'a precedent slavishly in circumstances to which it is not appropriate having regard to reality': at 509 and 512. See V Crabbe, Legislative Drafting (London 1993), p 112.

43 See, in particular, Ghaidan v Godin Mendoza [2004] UKHL 30 in which the House of Lords held that the words 'living with the original tenant as his or her wife or husband' in the Rent Act 1977 should be reinterpreted to include a person in a same-sex partnership in order to be compatible with Arts 8 and 14 ECHR, following the similar decision of the European Court in Karnerv Austria [2003] ECHR 40016/98. Compare this with the decision of the House of Lords in Fitzpatrick $v$ Sterling Housing Association Limited [2001] 1 AC 27 prior to the incorporation of Art 8, in which it was held that a 
willingness of the courts to chip away at the concept of the family to include homosexual "family life" within its ambit', ${ }^{44}$ though there remain exceptions ${ }^{45}$ to this trend towards purposive interpretation. ${ }^{46}$

The Human Rights Act 1998 has also prompted statutory change furthering the rights of same-sex couples. ${ }^{47}$ An example may be found in the Gender Recognition Act 2004, which was the consequence of both unfavourable judgments by Strasbourg ${ }^{48}$ and the House of Lords, ${ }^{49}$ who made a Declaration of Incompatibility under the Human Rights Act 1998. The Gender Recognition Act 2004 provides, inter alia, that transsexuals who have obtained gender recognition certificates may marry someone of the opposite sex to the one that they have newly acquired..$^{\circ}$ The importance of the Human Rights Act 1998 as a precursor to the new law on discrimination and the Civil Partnership Act 2004 is also important. The Human Rights Act 1998 may therefore be seen as the base of the new 'law on sexual orientation'.

\section{THE CIVIL PARTNERSHIP ACT 2004}

As Cretney has observed, there is a 'remarkable paradox' behind the creation of the Civil Partnership Act 2004: ironically, concerns about the rights of unmarried heterosexual couples promoted legislation which dealt solely with the rights of same-sex couples..$^{51}$ The Civil Partnership Act was introduced by the Government in response to two private member's Bills, which both sought to introduce a mechanism for both homo- and heterosexual couples. However,

homosexual partner could accede to the tenancy but only as a member of the deceased's 'family' and not as a person living with him 'as his husband or wife' since those words were gender-specific. See N Lowe and G Douglas, Bromley's Family Law (tenth edition, Oxford, 2007), pp 1102-1104.

44 G Douglas, An Introduction to Family Law (second edition, Oxford, 2004), p 54.

45 See $R v$ Pearce [2001] EWCA Crim 2834, [2002] 1 WLR 1553 concerning the definition of spouse in respect of the competence and compellability of witnesses in criminal proceedings.

46 For further evidence of this trend see Mv Secretary of State for Work and Pensions [2003] EWCA Civ 1343, concerning the definition of 'family' in the Child Support (Maintenance Assessment and Special Cases) Regulations 1992. See also the discussion in Saunders v Garrett [2005] WTLR 749. See M Hill, 'Rent Asunder: Westminster's War on Marriage', paper presented at Tenth Anniversary Conference, Centre for Law and Religion, Cardiff University, 11-12 March 2008, available from <http://www.ecclaw.co.uk/articles.php>.

47 The significance of the ECHR in the legislative development of English law has accelerated postincorporation, 'though perhaps not as much as some anticipated': Lowe and Douglas, Bromley's Family Law, p 24.

48 Goodwin v United Kingdom [2002] ECHR 28957/95, (2002) 35 EHRR 447.

49 Bellinger v Bellinger [2003] 2 AC 467.

50 See S Gilmore, 'The Gender Recognition Act 2004' [2004] Family Law 741.

51 He notes that the at the time of the 2001 census, there were more than four million people living in a opposite sex relationship without marriage, 'a significant group, often unknowingly exposed to the serious risk of hardship and injustice because their relationship was only given very restricted legal recognition'. In contrast, he notes that 'the number cohabiting in same sex relationships was much smaller': Cretney, Same Sex Relationships, p 15. 
unlike these Bills, ${ }^{52}$ the civil partnership legislation only provided recognition and protection in the case of 'a relationship between two people of the same sex' which is either formed 'when they register as civil partners of each other' or 'by virtue of having registered an overseas relationship'. ${ }^{53}$

The Act clearly represents an advance in the protection afforded to same-sex couples. However, the affect of the Act upon religious believers is unclear for two reasons. First, it is unclear what the precise difference is between a civil partnership and a marriage and this is important since for many religious believers marriage has an important religious significance. Second, the exclusion of religion from civil partnership ceremonies has been controversial and has led to recent legislative changes which further muddy understandings of what a civil partnership is. The following examines these two issues in turn. ${ }^{54}$

\section{The difference between civil partnerships and marriage}

There has been a heated debate as to the differences between civil partnerships and marriages. The Labour Government's intention was to create 'a parallel but different legal relationship' to marriage. ${ }^{55}$ And they sought to do this by using 'civil marriage as a template for the processes, rights and responsibilities that go with civil partnership'. ${ }^{6}$ Section after section of the legislation relating to marriage and divorce was simply been copied into the Act. ${ }^{57}$ Much of the law on the restrictions, formation and dissolution of civil partnerships are the same as for civil weddings, for example. ${ }^{58}$ However, there are certain differences

52 Cretney comments that this may be because 'unmarried different sex couples had no well organised pressure groups pressing their interests'. However, he also notes that priority may have been given to same-sex unions on the basis that it can be argued that heterosexuals have the option of marriage. See ibid, p 16. It is also likely that priority was given to same-sex unions as a result of judicial activism under the Human Rights Act 1998.

53 Civil Partnership Act 2004, s 1(1).

54 See also P Edge and D Corrywright, 'Including religion: reflection on legal, religious and social implications of the developing ceremonial law of marriage and civil partnership,' (2011) 26(1) Journal of Contemporary Religion 19 and M Hill, 'Church, state and civil partners: establishment and social mores in tension' in N Doe and R Sandberg (eds) Law and Religion: new horizons (Leuven, 2010) p 57.

55 Jacqui Smith, HC Deb 9 November 2004 c 776. This has been recognised by the courts: see Wilkinson v Kitzinger [2006] EWHC 2022 (Fam), where it was noted that the Act bestows upon civil partners 'effectively all the rights, responsibilities, benefits and advantages of civil marriage save the name' (at para 121). Compare, however, the words of the then Deputy Equality Minister Meg Munn, who launched a campaign to promote awareness of the Act at Westminster registry Office in September 2005 with the declaration that there would be 'no legal difference between a civil partnership and a marriage'. See Cretney, Same Sex Relationships, p 19.

56 Jacqui Smith, HC Deb 9 November 2004 c 776.

57 This was perhaps an appropriate compromise but it ducked the question of what the essence of a civil partnership is. It is also questionable given that the current legislation on marriage and divorce is not universally regarded as being fit for purpose in the 21st century.

58 The restrictions on who can enter a civil partnership match those for marriage but for the requirement that the partners must be of the same sex. See Civil Partnership Act 2004, ss 3 and 4 . Civil partners must be over 16 years old. Those under 18 years old need parental consent. They must not be married or already be a civil partner. They must not be within the prohibited degrees of 
regarding termination which may shed some light on how a civil partnership is different to a marriage. Like marriage, a civil partnership 'ends only on death, dissolution or annulment'. ${ }^{9}$ However, although the provisions of the Civil Partnership Act 2004 as regards termination 'mirrors, to a large extent, the provisions contained in the Matrimonial Causes Act $1973^{, 60}$ (with the order of dissolution being equivalent to a divorce), there are two main differences between the termination of a marriage and termination of a civil partnership. ${ }^{61}$ First, whilst adultery is a ground for a divorce, ${ }^{62}$ it is not a ground for the dissolution of a civil partnership. ${ }^{6} 3$ Second, in relation to annulment, whilst section 12 of the Matrimonial Causes Act 1973 provides that a marriage may be voidable if one party petitions that the marriage has not been consummated, ${ }^{64}$ there is no equivalent provision to that in the Civil Partnership Act 2004. ${ }^{65}$ These differences would seem to suggest that sexual intimacy is not a definitive element of a civil partnership. ${ }^{66}$ As Cretney has observed, whilst the Act makes it clear that 'a civil partnership is a "relationship" between two people of the same sex, ... Parliament has not been prepared to ordain that it should necessarily be a sexual relationship', ${ }^{67}$

Much has been made of this distinction by some religious groups; most notably by the House of Bishops of the Church of England who noted that clergy were free to enter a civil partnership since that act of registration does

relationship. The formation of a civil partnership is analogous to a civil wedding but for the fact that whilst in a wedding ceremony it is the exchanging of vows that forms the marriage (Marriage Act 1949 S (1), S44 (3)), a civil partnership is technically formed once both partners have signed the civil partnership document (Civil Partnership Act 2004, S 2(1)). However, note Cretney's comment that 'in practice Civil Partnership Registrars will often include an exchange of words of mutual commitment by the parties': Cretney, Same Sex Relationships, p v.

59 Civil Partnership Act 2004, s 1(3).

60 Gray and Brazil, Blackstone's Guide to the Civil Partnership Act 2004, p 25.

61 See Hill, 'Church, state and civil partners', p 57.

62 Matrimonial Causes Act 1973, s1(2) (a).

63 Although a relationship with a third party may constitute the ground of 'behaviour' under s 44(1) of the Civil Partnership Act 2004: see Lowe and Douglas, Bromley's Family Law, p 301 and Gray and Brazil, Blackstone's Guide to the Civil Partnership Act 2004, p 27.

64 Owing to the incapacity of either party to consummate or that it has not been consummated due to the respondent's wilful refusal to do so: Matrimonial Causes Act 1973, s 12 . Section 12 also provides that a marriage may be voidable if one of the parties was suffering from a communicable venereal disease at the date of the marriage. See Lowe and Douglas, Bromley's Family Law, p 79.

65 See Civil Partnership Act 2004, s 50.

66 See Hill, 'Church, state and civil partners', p 57. For a different view, see J Humphreys, 'The Civil Partnership Act 2004, same-sex marriage and the Church of England', (2006) 8 Ecc LJ 289.

67 Cretney, Same Sex Relationships, p 34. Support for this can be found in the legislative history, in which it is stated: 'There is no provision for consummation in the Civil Partnership Bill. We do not look at the nature of the sexual relationship, it is totally different in nature': Baroness Scotland, HL Deb 17 November 2004 C 1479. See also the judgment of the European Court of Human Rights in Burden $v$ United Kingdom, which despite upholding the prohibition on sisters entering a civil partnership proclaimed that 'Rather than the length or the supportive nature of the relationship, what is determinative is the existence of a public undertaking, carrying with it a body of rights and obligations of a contractual nature': [2008] ECHR 13378/05, para 65. 
not of itself constitute a declaration of homosexual practice. ${ }^{68}$ However, such neat distinctions are not to be found in the Act itself. As Cretney notes, the Civil Partnership Act does not answer the question of what a civil partnership is about. ${ }^{6} 9$ The rules as to formation and termination tell the parties nothing about 'what is involved in the relationship which they have created' 70 'This is the same as the legislation applicable to marriage and divorce. However, whilst social, moral and religious ideas about the nature of marriage have developed and evolved over the centuries, little thought has been given to determining the essence of a civil partnership. ${ }^{71}$ It is therefore somewhat inevitable that marriage has been used as the frame of reference against which civil partnerships are compared and contrasted with. The facilitative but vague nature of the Civil Partnership Act renders it difficult to extrapolate the differences between marriages and civil partnerships. ${ }^{72}$ This conceptual uncertainty poses problems in terms of promoting equality on grounds of both sexual orientation and religion.

\section{'Religious' civil partnerships?}

One significant and 'real' difference which is found in the Act is that same-sex couples cannot choose to have a religious civil partnership. ${ }^{73}$ In the same way as a religious service cannot be used during a civil marriage ceremony, ${ }^{74}$ a religious service cannot be used 'while the civil partnership registrar is officiating at the signing 75 and the place at which two people may register as civil partners must not be in 'religious premises'. ${ }^{76}$ It is possible to see both pragmatic and

68 A Pastoral Statement issued by the House of Bishops of the Church of England on 25 July 2005 stated that the Act left 'entirely open the nature of the commitment that members of a couple chose to make to each other when forming a civil partnership. In particular, it is not predicated on the intention to engage in a sexual relationship'.

69 Cretney, Same Sex Relationships, p 22.

70 Ibid, p 23.

71 As Cretney puts it, in a wedding 'you have to say that you are taking your partner as your wife or husband, and those two nouns historically attracted almost universal recognition. But this is not true of "civil partnership" which is a creature of the twentieth and twenty-first centuries': Cretney, Same Sex Relationships, p 26.

72 This vagueness poses obvious problems for religious groups and believers in terms of potential conflicts with their beliefs. If it is unclear what a civil partnership is, then it is likely to be unclear whether there is doctrinal incompatibility. See, in particular, the decision in McClintock $v$ Department of Constitutional Affairs [2008] IRLR 29, in which a Justice of the Peace wished to be exempt from obligations under the Civil Partnership Act which may have led him to place children with homosexual couples. His claim of religious discrimination was unsuccessful because McClintock had never made it plain that his objection was underscored by conscientious or religious objection.

73 Cretney, Same Sex Relationships, p 25.

74 Marriage Act 1949, s 45 A(4). Civil marriages can either occur in a registrar office or in approved premises. A building with a recent or continuing religious connection cannot be approved premise: Marriages and Civil Partnerships (Approved Premises) Regulations 2005/3168, Sch 1.

75 Civil Partnership Act 2004, s 2(5).

$76 \mathrm{~S} 6(1)(\mathrm{b})$. That is, premises which are either 'used solely or mainly for religious purposes; or 'have been so used and have not subsequently been used solely or mainly for religious purposes': s 6(2). 
principled reasons for this. Pragmatically, this neatly defused opposition from some traditional Christian churches. ${ }^{77}$ On a more principled level, this is in line with the Labour Government's intention to use 'civil marriage as a template' for civil partnerships. ${ }^{78}$ However, objections to this ban were raised. It was considered to be discrimination that whilst a couple contemplating marriage has a religious choice in addition to the non-religious civil marriage: ${ }^{79}$ same-sex couples, by contrast, could only have a civil ceremony. ${ }^{80}$ A religious ceremony (a 'blessing') could follow, but without any legal effect and on different premises. $^{81}$

The desire of some religious groups to conduct and register civil partnerships eventually led to amendments being tabled to what was to become section 202 of the Equality Act $2010 .{ }^{82}$ During the committee stage in the House of Lords, a 'permissive' amendment was tabled which would have allowed civil partnerships to take place on religious premises. ${ }^{83}$ Although several of their Lordships spoke in favour of the amendment (with Baroness Campbell, for example conceiving 'the issue as a matter of religious freedom' $)^{84}$ a number of objections were raised, most notably that changes to 'civil' partnerships would affect 'civil' weddings and would therefore 'blur the distinctions between civil and religious marriage as two paths to effect what is in law the same relationship. ${ }^{85}$ This resulted in the amendment being withdrawn in

77 See Cretney, Same Sex Relationships, p 25.

78 Jacqui Smith, HC Deb 9 November 2004 c 776.

79 To be more accurate, they have religious choices: see Lowe and Douglas, Bromley's Family Law, pp 59-60.

80 Evidence suggests that such a choice would be welcomed: a survey of same-sex couples found that a significant minority wanted a religious element in a civil partnership celebration: P Readhead, Same-Sex Couples Tie the Knot (ESRC, 2006).

81 In the same way as a religious ceremony ('a blessing') may follow a civil wedding, a similar religious ceremony could follow a civil partnership ceremony. However, in both cases, it is the civil ceremony which is legally binding: Marriage Act 1949, ss 45(2) and 46. The provision and form of such a religious ceremony is a matter of choice for the religious group asked. See the Pastoral Statement issued by the House of Bishops of the Church of England on 25 July 2005 that 'affirms' that clergy of the Church of England should not provide services of blessing for those who have registered a civil partnership but 'where clergy are approached by people asking for prayer in relation to entering into a civil partnership they should respond pastorally and sensitively in the light of the circumstances of each case'. For a critique see B Lewis, 'What services are Clergy permitted to offer couples in same sex relationships in the Church of England?' < http://thinkinganglicans.org.uk/uploads/brianlewis. html $>$.

82 See the Resolution passed in 2008 by the General Assembly of Unitarian and Free Christian Churches (Resolution 7: available at <www.unitarian.org.uk/info/ga-resolutions2008.shtml >) and the Minutes of the 2009 Yearly Meeting of the Society of Friends (Quakers) (minute 23: available at <www.quaker.org.uk/sites/default/files/YMG-2009-minutes.pdf $>$.

83 The amendment was tabled by Lady Campbell of Surbiton, Lady Neuberger, Lady Noakes and Lord Ali. As Baroness Neuberger explained, the amendment 'would mean a civil partnership taking place within a Quaker meeting house, for example ... followed by some kind of faith-based commitment ceremony, the second following materially from the first'. HL Deb 25 January 2010 c 1199.

84 At c 1201.

85 Bishop of Winchester at c 1202. See also Lord Hunt of Wirral at c 1206. Note also the Bishop of Chichester's concern that the removal of the ban would put pressure 'not on the national institution 
light of the Minister's commitment to look at the issue further. ${ }^{86}$ Following a vote in favour of removing the bar at report stage, the Government brought forward its own amendment at third reading. This sought to amend the Civil Partnership Act 2004 to remove the ban on civil partnerships taking place on religious premises, ${ }^{87}$ to add a power to create Regulations to approve premises that may include 'religious premises', 88 and to insert a new section into the Civil Partnership Act 2004 stating that, 'For the avoidance of doubt, nothing in this Act places an obligation on religious organisations to host civil partnerships if they do not wish to'. ${ }^{89}$ This amendment, now section 202 of the Equality Act 2010, is not yet in force. At the time of the third reading, it was promised that 'there would be extensive consultation before these powers are used'.90 However, since then there has been a change of Government and to date the new Coalition Government have simply said that they are consulting whether to bring the power into force. ${ }^{91}$

If section 202 is brought into force, one of the few clear defining attributes of civil partnerships will be lost and the relationship between civil partnerships and marriage will be clouded in yet more uncertainty. It will no longer be the case that civil partnerships are analogous to civil weddings: civil partnerships will not be 'civil'; they will no longer share one of the, if not the, key definitional attributes of civil weddings. ${ }^{92}$ This lack of clarity will be in keeping with much of the character of the Civil Partnership Act itself. The Act extends the rights afforded to same-sex couples but does so in a haphazard way characterised by an

of the Church of England but on the incumbents of the parishes and lead to widespread disarray throughout the Church of England' (c 1203).

86 The Minister concluded that the amendment was 'not a workable solution to this issue' since it would 'lead to inconsistencies with civil marriage, have an unexplored impact on devolved Administrations and lead to confusion on what is permitted and what is required' (Baroness Thornton at c 1208).

87 Equality Act 2010 s 202(1) omits sections 6(1)(b) and (2) of the Civil Partnership Act. The ban on religious services whilst the registrar if officiating under $\mathrm{S} 2(5)$ is untouched.

88 Equality Act $2010 \mathrm{~S} \mathrm{202(3)} \mathrm{states} \mathrm{that} \mathrm{these} \mathrm{Regulations} \mathrm{'may} \mathrm{provide} \mathrm{that} \mathrm{premises} \mathrm{approved} \mathrm{for} \mathrm{the}$ registration of civil partnerships may differ from those premises approved for the registration of civil marriages' which may include in particular to 'religious premises'. They may 'make provision in relation to religious premises that differ from provision in relation to other premises' and may 'make different provision for different kinds of religious premises'.

89 Equality Act 2010 s 202(4) would insert this definition into a new section 6A(3A). Definitions of 'civil marriage' and 'religious premises' would be inserted as $6 \mathrm{~A}(3 \mathrm{~B})$ and $6 \mathrm{~A}(3 \mathrm{C})$ respectively.

90 Baroness Royall of Blaisdon, HL Deb 23 March 2010 c 871.

91 The Coalition's new Equality Strategy, published in December 2010, said that it was talking with 'representatives of faith and lesbian, gay and bisexual groups, about what the next stage should be for civil partnerships, and including how some religious organisations can allow same-sex couples the opportunity to register their relationship in a religious setting if they wish to do so': HM Government, The Equality Strategy - Building a Fairer Britain (December 2010), p 21.

92 See the comments of Lord Lester at Third Reading: 'When we introduced the Civil Partnership Bill, we used civil marriage as the analogue to create civil partnership. What we are doing here is allowing a religious aspect to civil partnership, because there cannot be a religious marriage. In the longer term, one may need to look at the consequences for civil marriage in relation to religion' HL Deb 23 March 2010 c 868. 
'ambiguity (or perhaps squeamishness) about the essential attributes of the relationship'. ${ }^{93}$ This poses problems not only in relation to discrimination on grounds of sexual orientation but also in relation to religious freedom. ${ }^{94}$ The original tactic of avoiding the issue by means of blanket exclusion has simply not worked. Reform, dialogue and compromises are fraught with difficulty due to the vagueness of the legislation. The law is currently uncertain and this is unsatisfactory in terms of promoting equality on grounds of both sexual orientation and religion or belief.

\section{STIRRING UP HATRED}

While civil partnerships provide an example of legislation enhancing the rights of same-sex couples which have been modified to enhance the rights of religious believers, ${ }^{95}$ provisions in the criminal law provides evidence of the reverse trend: the modification of legislation that was enacted to protect religion in order to protect homosexual rights. As is well known, the Racial and Religious Hatred Act $2006^{96}$ controversially amended the Public Order Act 1986 to create 'offences involving stirring up hatred against persons on religious grounds' ${ }^{97}$ It created numerous criminal offences protecting groups of believers from being threatened in a way that is defined by reference to religious belief or lack of religious belief. It is less well known, however, that section 74 of the Criminal Justice and Immigration Act 2008 amended Part 3A of the Public Order Act 1986 to also cover hatred 'on grounds of sexual orientation'. ${ }^{8}$ The amendments made by the 2008 Act largely serve to add the words 'or hatred on grounds of sexual orientation' to the various offences created by the Racial and Religious Hatred Act 2006.99

This was particularly surprising since the provisions found in the Racial and Religious Hatred Act 2006 differed from what the then Government had

93 S Cretney, Same Sex Relationships, p 37.

94 As shown by the cases of Ladele v London Borough of Islington [2009] EWCA Civ 1357 and McFarlane $v$ Relate Avon Ltd [2010] EWCA Civ 880 discussed below.

95 If s 202 of the Equality Act 2010 ever comes into force.

96 For a full account, see I Hare, 'Crosses, crescents and sacred cows: criminalising incitement to religious hatred', [2006] Public Law 521; and K Goodall, 'Incitement to religious hatred: all talk and no substance', (2007) 70(1) MLR 89.

$97 \mathrm{~S} 29$ A defines religious hatred as 'hatred against a group of persons defined by reference to religious belief or lack of religious belief'.

$98 \mathrm{~S} 29 \mathrm{AB}$ defines hatred on grounds of sexual orientation as 'hatred against a group of persons defined by reference to sexual orientation (whether towards persons of the same sex, the opposite sex or both)'.

99 The 2008 Act does make some minor amendments which apply to both religious hatred and hatred on the grounds of sexual orientation. Some of the differences between the enforcement of the crimes in England and Wales and Scotland are deleted, the sentencing is altered and the National Assembly for Wales is now exempted, remedying an anomaly in the Racial and Religious Hatred Act 2006 which provided an exemption for the Westminster and Scottish Parliaments. 
intended. Due to defeats during the Parliamentary passage of the Bill, the Act not only provided that a prosecution could only be brought if the defendant intended to stir up religious hatred ${ }^{100}$ but also inserted a freedom of speech clause into the final Act. ${ }^{101}$ These decreased the likelihood of a successful prosecution under the Act. These same restrictions apply in the new criminal offences of stirring up hatred on grounds of sexual orientation. As with the law on religious hatred, the act of the defendant must be threatening and there must be an intention to stir up hatred. ${ }^{102}$ Moreover, a section protecting freedom of expression, similar but not identical to, that which exists in relation to religious hatred has been included. ${ }^{103}$

There are now two offences of stirring up hatred on the statute books which are both narrower than the Labour Government had intended. Questions expressed about the likelihood of a successful prosecution for religious hatred equally apply in relation to hatred on grounds of sexual orientation. Whilst unsurprisingly there has been a lack of reported court decisions on these criminal offences, their importance to the new law on religion and the new law on sexual orientation ought not to be overlooked for two reasons. First, it is noteworthy that in both cases exceptions were provided but that these were on grounds of free speech not religious freedom. Second, the criminal law approach of dealing sexual orientation and religion in the same way is significant since the same approach has been followed in discrimination law: in the Equality Act 2010 'religion and belief' sits alongside seven other 'protected characteristics', including sexual orientation. This is noteworthy because there

100 The Government had wanted the offence to be charged either when the defendant had the intention to stir up religious hatred or was being reckless as to whether religious hatred would be stirred up thereby. The Government had also wanted to include 'abusive or insulting' words or behaviour in addition to 'threatening'. See N Addison, Religious Discrimination and Hatred Law (London, 2007), pp 139-141.

101 Section 29J provides: 'Nothing in this Part shall be read or given effect in a way that prohibits or restricts discussion, criticism or expressions of antipathy, dislike, ridicule, insult or abuse of particular religions or the beliefs or practices of their adherents, or of any other belief system or the beliefs of practices of its adherents, or proselytising or urging adherents of a different religion or belief system to cease practising their religion or belief system.' However, the value of this statement is open to debate.

102 Dr Evan Harris noted that: 'On Second Reading, the Secretary of State agreed that it was right that a new offence of inciting homophobic hatred should be closer to the religious hatred end rather than the race hate end of the spectrum, in that such incitement would have to be intentional, and the provision should deal with threatening words and behaviour only': HC Deb 9 January 2008 c 448 .

103 Inserted section 29JA reads, 'In this Part, for the avoidance of doubt, the discussion or criticism of sexual conduct or practices or the urging of persons to refrain from or modify such conduct or practices shall not be taken of itself to be threatening or intended to stir up hatred'. The clause was requested, inter alia, by the Church of England and the Roman Catholic Church in a rare joint submission to the Public Bill Committee. Jim Dobbin suggested that the clause in relation to sexual orientation is 'narrower and less far reaching': HC Deb 9 January 2008 c 450. In the end, the clause was inserted into the Bill by the House of Lords against the wishes of the Government. 
are concerns that religion or belief is different from the other 'protected characteristics' and ought to be protected differently. ${ }^{104}$

\section{DISCRIMINATION ON GROUNDS OF RELIGION AND SEXUAL ORIENTATION}

Developments in discrimination law represent perhaps the most important part of the new law. In compliance with EU law, ${ }^{105}$ discrimination on grounds of sexual orientation and religion or belief was prohibited at first in relation to

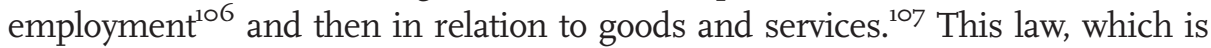
now to be found in the Equality Act 2010, has led to two significant areas of concern where there has been a clash between these two equality streams. First, a series of high-profile cases has been brought by religious individuals (typically employees) who are obligated to act in certain ways by the new laws protecting sexual orientation which they feel clash with their religious convictions. Second, the existence and scope of exceptions allowing religious groups and employers to discriminate on grounds of sexual orientation has led to numerous heated debates both inside and outside Parliament. The following examines these two controversies in turn, paying most attention to the second issue. ${ }^{108}$

\section{Litigation brought by employees}

A number of claims have been brought by employees who have been forced to carry out obligations arising from new laws protecting sexual orientation. All of these cases asserting that their employer's insistence that they carry out these obligations constitutes religious discrimination have failed. ${ }^{\circ}{ }^{\circ}$ The two leading cases are the Court of Appeal decisions in Ladele $v$ London Borough of Islington $^{110}$ concerning a registrar threatened with dismissal because she refused on grounds of conscience to perform civil partnership ceremonies

104 As Sedley LJ held in Eweida $v$ British Airways [2010] EWCA Civ 80 at para 40, whilst all of the other protected characteristics apart from religion or belief 'are objective characteristics of individuals; religion and belief alone are matters of choice'.

105 In 2000, EU Directive 2000/78/EC stated that, in addition to existing prohibition against discrimination on grounds of sex and race, discrimination on grounds of sexual orientation, age, disability and religion or belief 'should be prohibited throughout the Community'.

106 Employment Equality (Religion or Belief) Regulations 2003 SI 2003/1660; Employment Equality (Sexual Orientation) Regulations 2003 SI 2003/1661.

107 Equality Act 2006, part 2; Equality Act (Sexual Orientation) Regulations 2007 SI 2007/1263.

108 The first issue has already been examined in depth in earlier editions of this journal. See, in particular, A Hambler, 'A no-win situation for public officials with faith convictions', (2010) 12 Ecc LJ 3; L Vickers, 'Religious discrimination in the workplace: an emerging hierarchy?', (2010) 12 Ecc LJ 280; and R Sandberg, 'Laws and religion: unravelling McFarlane v Relate Avon Ltd', (2010) 12 Ecc LJ 361.

109 See also the decision in McClintock v Department of Constitutional Affairs [2008] IRLR 29, discussed in Sandberg, Law and Religion, pp 106-107.

110 [2009] EWCA Civ 1357. 
and McFarlane v Relate Avon $\mathrm{Ltd}^{111}$ concerning a Christian counsellor who was dismissed because he refused to counsel same-sex couples on sexual matters. In both cases, the Court of Appeal held that claims of direct discrimination on grounds of religion failed because the employer did not treat the employee unfavourably on grounds of religion. Although Ladele and McFarlane's actions were on grounds of religion, their employer's actions were not. Claims of indirect discrimination were also dismissed on the basis that any disadvantage was justified. In both cases, the Court of Appeal held that the employer's policy of promoting equality on grounds of sexual orientation constituted a legitimate aim. As the Court of Appeal put it in Ladele, the Council's policy was 'of general, indeed overarching, policy significance to Islington, and it also had fundamental human rights, equality and diversity implications, whereas the effect on Ms Ladele of implementing the policy did not impinge on her religious beliefs: she remained free to hold those beliefs, and free to worship as she wished'. ${ }^{112}$ In short, the obligations on the employer not to discriminate on grounds of sexual orientation trumped the rights of the employee not to be discriminated against on grounds of religion or belief. There seems to be no recognition that equality policy protects discrimination on grounds of religion as well as on grounds of sexual orientation.

These cases can be contrasted with a recent case brought under the law prohibiting discrimination on grounds of sexual orientation. Hall and Preddy $v$ Bull and Bull ${ }^{113}$ concerned a private hotel which had a policy that 'out of a deep regard for marriage' they 'preferred to let double accommodation to heterosexual married couples only'. When the claimants, two men who had entered a civil partnership, were refused the double room, they contended that this constituted direct or indirect discrimination on grounds of sexual orientation. The judgment of the County Court was that there had been both direct and indirect discrimination. In terms of direct discrimination, the County Court did not accept the defendant's argument that their actions were because of their views on sex outside marriage and not their views on homosexuality. ${ }^{114}$ This seems at odds with Ladele and McFarlane, where a great emphasis was given to the respondent's motive. In terms of indirect discrimination, the County Court held that the discrimination had not been justified. Interestingly the judgment of the court does not mention the grounds upon which the discrimination could be justified and suggests that it would be difficult to identify such grounds, noting that, in contrast, it would be 'easy to imagine examples of such cases'

111 [2010] EWCA Civ 880.

112 [2009] EWCA Civ 1357 at para 51.

113 Bristol County Court (Case Numbers 9BSo2095 and 9BSo2096) Judge Andrew Rutherford.

114 See para 37: 'on a proper analysis of the defendants' position on the facts of this particular case the only conclusion which can be drawn is that the refusal to allow them to occupy the double room which they had booked was because of their sexual orientation'. 
in the sphere of religious discrimination. ${ }^{115}$ The judgment suggests that it is more difficult to justify indirect discrimination on grounds of sexual orientation than it is to justify such discrimination on grounds of religion. ${ }^{116}$

Although at time of writing this case has only been heard at the County Court, ${ }^{117}$ there seems to be a staggeringly different approach at play here to that which was employed in Ladele and McFarlane. In those cases, the employer's concerns about sexual orientation equality trumped the employee's right not to be discriminated on grounds of religion or belief. In contrast, in Hall and Preddy $v$ Bull and Bull when the service provider's concerns about religious freedom clashed with the customer's right not to be discriminated against on grounds of sexual orientation, the customer won. Ladele and McFarlane illustrate how difficult it is for religious individuals to exempt themselves from the obligations placed on employees by the new law on sexual orientation. It is clear that the way in which they are treated by the law differs greatly from religious groups. The law offers very little, if any, accommodation of their views. Despite being in the job far before the advent of the new law on sexual orientation discrimination, the only option for employees is the right to resign. In contrast, religious groups and employers enjoy a greater level of protection. Laws prohibiting discrimination on grounds of sexual orientation make some concession to religious groups and religious employers whose religious beliefs clash with obligations placed on them by providing statutory exceptions.

\section{Exceptions afforded to religious groups and employers}

The Equality Act 2010 provides a number of exceptions for religious groups. ${ }^{118}$ These include separate religious exceptions from the law prohibiting sexual orientation discrimination allowing religious groups to discriminate in relation to employment ${ }^{119}$ and the provision of goods and services. ${ }^{120}$ The wording of

115 See para 52: 'The Sikh who would have been required to wear a crash helmet when riding a motorbicycle if a specific exemption had not been created by the Road Traffic Act 1998. This would have discriminated against his religion but could arguably be justified on the grounds of road safety. The requirement to wear a particular uniform at work may cut across a person's religious beliefs but may be justified again on health and safety grounds or to promote a particular corporate identity'.

116 Much of the case turned on the fact that they were civil partners and under discrimination law no distinction should be made between married couples and civil partners. It would be interesting to see if the same decision would be reached if the claimants were a same-sex couple who had not entered into a civil partnership.

117 Permission to appeal was granted by the first instance judge in the County Court: see paras 62 and 63.

118 Exceptions from laws prohibiting discrimination on grounds of sex and religion or belief are also provided for religious groups and employers. For an analysis of the law before the Equality Act 2010, see R Sandberg and N Doe, 'Religious exemptions in discrimination law', p 302. For analysis of the law under the Equality Act 2010, see Sandberg, Law and Religion, chapter 6.

119 Sch 9, para 2.

120 Sch 23, para 23 . 
these exceptions closely follows those found in the previous law ${ }^{121}$ since attempts to modify the terms of these exceptions were defeated as part of the Parliamentary passage of the Bill. ${ }^{122}$ The Labour Government had wanted to amend the terms of these exceptions, claiming that these amendments simply sought 'to clarify, not to change' the law. ${ }^{123}$ However, opponents saw these amendments as narrowing the terms of the exceptions and successfully sought to remove them, claiming that they were seeking to retain the status quo. ${ }^{124}$

This was simply the latest in a long line of controversies surrounding these exceptions. They have been the subject of numerous Parliamentary debates, reported clashes within both the Blair and Brown cabinets, and important litigation. Indeed, the hullabaloo concerning the existence and scope of these exceptions may not be over. In November 2009 the European Commission sent a reasoned opinion to the UK Government asserting that exceptions for religious employers under UK law were broader than those permitted under the EC Directive. Although the Government responded by saying that it was studying this reasoned opinion, ${ }^{125}$ the defeat of the reconfigured exceptions in the Equality Act 2010 raises the question of whether the exceptions could now be subject to challenge under EU law. ${ }^{126}$

The scope of the employment exception has proved particularly contentious. The exception from the law prohibiting discrimination on grounds of sexual orientation in relation to employment, now found in Schedule 9 to the Equality Act 2010, applies where three criteria are met. ${ }^{127}$ First, the employment must be 'for the purposes of an organised religion'. The use of the phrase 'for the purposes of organised religion' seems intended to limit the ambit of the exception. The Explanatory Notes state that this is intended to cover a very narrow range of employment: ministers of religion and a small number of lay

121 Employment Equality (Sexual Orientation) Regulations 2003, reg 7(3) and Employment Equality (Sexual Orientation) Regulations 2007, reg 14.

122 As were other amendments such as the amendment tabled by Lord Alli which would have removed the 'unpleasant and spiteful' employment exception in order to 'offer priests the same employment protections in relation to their sexuality as other members of society'. See HL Deb 25 January 2010 c 1198.

123 'The Government's intention is not and never has been to narrow the scope of the existing exception': Baroness Royall of Blaisdon at c 1214 .

124 See for instance the comments of Baroness O'Cathtrain at c 1212: 'If the Government's intention was to maintain the status quo, as they have said continuously since April 2009, why not use the same wording? After all, it has been in use without difficulty since 1975, when it was incorporated in the Sex Discrimination Act. By tinkering, they have caused enormous concern among religious groups. It is essential that the wording is returned to what it was. All the religious groups and their lawyers say that the result of my amendments would be the retention of the status quo. That is what we want-nothing more and nothing less'.

125 See F Cranmer, 'Parliamentary Report', (2010) 12 Ecc LJ 229, pp 233-234.

126 A previous challenge in $R$ (Amicus MSF Section) $v$ Secretary of State for Trade and Industry [2004] EWHC 860 was unsuccessful on the basis that it was clear from the parliamentary material that the exceptions were intended to be of very narrow scope, tightly drawn and were to be construed strictly. See para 103 .

127 See para 2. 
posts, including those that exist to promote and represent religion'. ${ }^{128}$ This is undoubtedly the meaning which would have been given to 'employment for the purposes of an organised religion' had the revised exceptions found in earlier drafts of the Equality Bill become law. The revised exception would have provided that it could only apply to someone whose employment 'wholly or mainly involves leading or assisting in the observation of liturgical or ritualistic practices of the religion, or promoting or expanding the doctrine of the religion'. This would have questioned the finding in Reaney $v$ Hereford Diocesan Board of Finance ${ }^{129}$ that employment as a Diocesan Youth Officer was for the purposes of an organised religion. ${ }^{130}$ The defeat of the Government's amendment seems to suggest that the phrase 'for the purposes of organised religion' is not just limited to ministers of religion and lay employees who promote and represent religion. However, Government Ministers argued that this was still the case despite the rejection of the amendment. Harriet Harman argued that the revised exception simply sought to 'make the distinction between religious and non-religious jobs clearer' but since the Lords did not regard the amendment as helpful the law remained as it was: 'in anti-discrimination law there is an exemption for religious jobs but not for non-religious jobs' ${ }^{131}$

These ministerial comments are questionable. ${ }^{132}$ Since no further definition of 'for the purposes of an organised religion' are now to be found in Schedule 9 to

128 Equality Act 2010 Explanatory Notes para 799.

129 [2007] Employment Tribunal, judgment 17 July 2007 (Case No 1602844/2006).

130 The organised religion was the Church of England and referring to the job application, job description and associated documents, the Tribunal concluded that the post fell within that small number of posts that were open to persons who were not clergy but which were nevertheless protected. See paras 100-102 of the judgment.

131 She further clarified that 'our position has always been that for specifically religious work-as a vicar, priest, rabbi or imam-religious organisations would be exempt from non-discrimination law. A religious organisation cannot discriminate against gay people or women when it hires a bookkeeper, but it can when choosing a minister of religion'. HC Deb 4 February 2010 c 468.

132 See also the comments of Baroness Royall of Blaisdon who stated that 'Employment "for the purposes of an organised religion" means a post, such as a minister of religion, involving work for a church, synagogue, mosque or temple. Ministers of religion are clearly in employment, "for the purposes of an organised religion"... The small number of posts outside the clergy to which paragraph 2 applies are those that exist to promote or represent an organised religion or to explain the doctrines of the religion. I should like to clarify that this does not mean that the post must involve only one or more of those activities, but one or more of them must be intrinsic to the post. By "representing" the religion, we mean acting or speaking for, and with the authority of, those in leadership within the religion. We therefore intend senior employees with representational roles, such as the secretarygeneral of the General Synod and the Archbishops' Council of the Church of England, to be within the definition. A further example is that of a senior lay post at the Catholic Bishops' Conference charged with acting on behalf of bishops when contributing to public policy developments. These are both roles where the emphasis is more representational than promotional. There will be similar such roles in other organised religions. An example of a post that exists more to promote the religion is that of a missionary working for a church in this country. A church youth worker who primarily organises sporting activities would be unlikely to be covered by the exception. However, a youth worker whose key function is to teach Bible classes probably would be covered, because explaining the doctrines of the religion would be intrinsic to the role ... It is certainly not our intention that the exception should apply to employees such as 
the Equality Act 2010, the previous case law on the topic remains good law. This includes statements in $R$ (Amicus MSF Section) $v$ Secretary of State for Trade and Industry ${ }^{133}$ that the term 'organised religion' is narrower than 'religious organisation ${ }^{\prime 34}$ but it also includes the finding in Reaney that employment as a Diocesan Youth Officer is within the definition. Whilst it is clear that the requirement that discrimination can only occur for the 'purposes of an organised religion' definitely narrows the scope of the exception, the scope of the exception is unclear. ${ }^{135}$

The second requirement is that the 'compliance' or 'non-conflict' principles must be engaged. Although these terms are new to the Equality Act, they are simply shorthand expressions to cover the reasons why the organised religion may discriminate (which remain largely unchanged). The compliance principle is engaged where the discrimination takes place 'so as to comply with the doctrines of the religion'. ${ }^{136}$ The non-conflict principle is engaged where the discrimination takes place 'so as to avoid conflicting with the strongly held convictions of a significant number of the religion's followers'. ${ }^{137}$ The exception found in earlier versions of the Equality Bill would have added a proportionality test. Although this test is not found in the text of the Act, ${ }^{138}$ the Explanatory Notes give the impression that it is: stating that the discrimination 'must be a proportionate way of meeting the criteria. ${ }^{139}$ This ambiguity is reflected in the Parliamentary debates. While opponents argued that the introduction of proportionality sought to narrow the scope of the exception, ${ }^{140}$ the Government

administrative staff, accountants, caretakers or cleaners ... In addition, the exception would not apply to most staff working in press or communications offices, although senior and high-profile roles within such offices that exist to represent or promote the religion would probably be within its scope': HL Deb 25 January 2010 cc 1215-1216.

133 [2004] EWHC 860.

134 Richards J gave the example that "employment as a teacher in a faith school is likely to be "for purposes of a religious organisation" but not "for purposes of an organised religion"' (para 116).

135 It is difficult to disagree with the words of the Archbishop of York in response to Baroness Royall of Blaisdon's speech quoted above: 'When I heard the Leader of the House describing what may be exempt, I said to myself, "My gosh, here comes a barrage of endless tribunals"': Archbishop of York, HL Deb 25 January 2010 c 1218.

136 Equality Act 2010, Schedule 9 Para 2(5).

137 In $R$ (Amicus MSF Section) v Secretary of State for Trade and Industry [2004] EWHC 860 Richards J stated that that these requirements imposed 'very real additional limitations' and suggested that both tests were objective (para 117).

138 The absence of a reference to proportionality also raises the question of whether or not the exception is broader than that permitted under EU law. As the Explanatory Memorandum on the EU Directive makes plain, a 'double test of a justified aim and proportionate means of reaching it ... is required': European Commission, Proposal for a Council Directive on implementing the principle of equal treatment between persons irrespective of religion or belief, disability, age or sexual orientation, Com (2008) 426 $2008 / 0140,8$.

139 Ibid.

140 See the comments of Baroness Butler-Sloss: "The introduction of the word "proportionate" in the two regulations inevitably changes the legal position. The word "proportionate" must mean something, and something more than the previous position because it was not there before ... Once you put a new word in it must be different. If this paragraph is challenged in the courts as a matter of 
contended that it would not, arguing that the proportionality requirement was already 'implicit' within the exception. ${ }^{141}$ This again suggests that there is an unhelpful air of confusion as to the scope of these exceptions. ${ }^{142}$

Even putting to one side the effect of the absence of an explicit reference to proportionality; the scope of the 'compliance' or 'non-conflict' principles remains unknown. Deciding whether a 'significant number' of followers may be offended is by no means a straightforward task. ${ }^{43}$ The only guidance is dicta in Reaney $v$ Hereford Diocesan Board of Finance, ${ }^{144}$ which suggests that the reference should be made to the national rather than local membership of the religion in question. ${ }^{145}$ Moreover, the reference to doctrine is also problematic. The courts are usually reluctant to engage in questions of doctrine. Although exceptionally the courts will need to examine questions of doctrine to resolve disputes about

interpretation or construction, a judge would ... be bound to find that there was a change. The effect would be to cause major problems for churches. There might be a situation where a church met the organised-religion test but could still lose a legal challenge in a particular case if a litigant argued that their action was disproportionate in his or her situation': HL Deb 25 January 2010 cc 1219-1220. See also the concerns of the Bishop of Winchester at c 1227: 'adding the word "proportionate" now is likely to change the interpretation that the courts will make of this legislation. It will require the courts to inquire into the precise nature of the particular religious doctrines in order to discover what is the minimum necessary to comply with them'.

141 Baroness Royall of Blaisdon at c 1235. This analysis was supported by Lord Lester of Cornhill, who suggested that the removal of the reference to proportionality would have no affect since proportionality was always part of the definition as it was required under EU law: 'It is the law under European law and it is the law of the land. Proportionality is required whether they like it or not' (c 1223). However, contrary to the view of Baroness Royall, Lord Lester did seem to suggest that the removal of the reference to proportionality would make a difference to the scope of the exception, noting that: 'Removing proportionality here, as these amendments seek to do, would mean that any religious organisation could implement the requirements without a sense of proportion and in breach of the general principle of European law' (c 1223). These two quotes are difficult to reconcile. Lord Lester's contribution later on in the debate seemed to suggest that removal would make a difference but that this difference would have no legal affect since the provision would need to be read in light of EU law which would mean that the proportionality requirement would be read back in: 'Of course there is a difference in the wording. But in each case, under the regulations and now, the European principle of proportionality has to be complied with. Therefore, it is highly beneficial that the law now makes it clear in the current wording, which is why the principle of proportionality is clearly spelt out. It does not change anything in existing law, since it was always the case, as the Amicus case demonstrates, that any exception must be strictly construed in accordance with European law' (c 1225).

142 As Baroness Deech put it, 'Court intervention in religious matters has not worked well. If, according to European law, we must be proportionate, writing that into the legislation is unnecessary because it is there anyway' (c 1230).

143 Indeed, in the case of some faiths it is further complicated by the lack of a definition of membership See the findings of the Colloquium of Anglican and Roman Catholic Canon Lawyers in J Conn, N Doe and J Fox (eds), Initiation, Membership and Authority in Anglican and Roman Catholic Canon Law (Rome, 2005) and P Colton, 'The pursuit of a canonical definition of membership of the Church of Ireland', (2007) 10 Ecc LJ 3-33.

144 [2007] Employment Tribunal, judgment 17 July 2007 (Case No 1602844/2006).

145 In that case, it was held that 'it would be unduly restrictive to consider the Church of England as being purely the Diocese of Hereford for the purposes of the interpretation of this regulation': para 104 . 
property or money, ${ }^{146}$ it is usually the case that 'courts will not attempt to rule upon doctrinal issues or intervene in the regulation or governance of religious groups..$^{47}$

The third requirement is that the employer can only discriminate either where the employee does not meet the requirement imposed or where the employer is not satisfied and it is reasonable for him not to be satisfied that that person meets it. The importance of this reasonableness requirement was stressed in Reaney $v$ Hereford Diocesan Board of Finance ${ }^{148}$ in which Reaney had been denied the job of Diocesan Youth Officer in Hereford after the Bishop refused to accept his assurance that he would remain celibate since he had been in a committed same-sex relationship. The Employment Tribunal found that Reaney did meet the requirement imposed and it was not reasonable for the Bishop to conclude otherwise. This meant that the Bishop could not rely upon the exception. Although Reaney provides an example of when the exception might be applied, ${ }^{149}$ the overall message seems to be that the exceptions are to be interpreted narrowly. ${ }^{150}$ The complexity of the provisions and the ambiguity of the language are likely to increase the likelihood of concern, tension and litigation.

The same is true of the exception allowing discrimination on grounds of sexual orientation in relation to goods and services, as now found in Schedule 23 to the Equality Act 2010. This is the same in substance as the old law. It applies where two criteria are met. First, the discrimination must be by 'an organisation relating to religion or belief'. ${ }^{151}$ This does not apply to an organisation 'whose sole or main purpose is commercial' ${ }^{152}$ or to anything done 'on behalf of a public authority' and 'under the terms of a contract between the organisation and a public authority'. ${ }^{153}$ This explains why the exception cannot be enjoyed by Catholic adoption agencies. Although Catholic adoption agencies are entitled to the exception in that they are 'organisations relating to religion or

146 Forbes v Eden (1867) LR 1 Sc \& Div 568. See also General Assembly of the Free Church of Scotland $v$ Lord Overtoun [1904] AC 515. See Sandberg, Law and Religion, chapter 4 and J Rivers, The Law of Organized Religions (Oxford, 2010), p 73.

147 HH Sant Baba Jeet Singh Maharaj v Eastern Media Group Ltd [2010] EWHC 1294 (QB) at para 5.

148 [2007] Employment Tribunal, judgment 17 July 2007 (Case No 1602844/2006).

149 Since the first two tests were met in that case, it can be assumed that the exception could have been relied on if Reaney had not met the requirement (eg if he had not made an assurance that he would be celibate).

150 This is especially clear in $R$ (Amicus MSF Section) $v$ Secretary of State for Trade and Industry [2004] EWHC 860 and the Explanatory Notes to the Equality Act 2010.

151 In relation to sexual orientation discrimination this is defined as '.. an organisation the purpose of which is' - 'to practice a religion or belief,' 'to advance a religion or belief,' 'to teach the practice or principles of a religion or belief,' or 'to enable persons of a religion or belief to receive any benefit, or to engage in any activity, within the framework of that religion or belief': Para $2(1) ; 2(11)$

152 Para $2(2)$.

153 The term 'public authority' is defined in section 150 of the Act as those which are specified in Schedule 19 . 
belief', they lose that exception when they contract with the State to provide their service. This proved controversial prior to the enactment of the Employment Equality (Sexual Orientation) Regulations $2007,{ }^{154}$ leading to a compromise whereby faith-based adoption and fostering agencies were given a specified time to adapt to the new regime. ${ }^{155}$ Following the end of this period of time, the matter has been subject to long-running litigation brought by Catholic Care which is still ongoing at time of writing. ${ }^{156}$ However, it would seem that there is little prospect of any change in the law on this matter. ${ }^{157}$

Second, an organisation can only discriminate on grounds of sexual orientation 'because it is necessary to comply with the doctrine of the organisation' or 'to avoid conflict with the strongly held convictions' of a 'significant number of the religion's [or belief's] followers' ${ }^{158}$ This mirrors the exception previously found in Regulation 14 of the Employment Equality (Sexual Orientation) Regulations 2007. Interestingly, although the grounds mirror those for employment in relation to sexual orientation, the 'compliance' or 'nonconflict' labels are not used in this context. This provides further evidence that the Equality Act 2010 has not fulfilled its purpose of consolidating the law making it easier to understand. The likelihood of further litigation and rebukes from the European Commission means that the current text of the Equality Act 2010 is unlikely to be the last word on the matter. And if current trends are to continue, it is likely that the narrowness of the exceptions will be continued to be stressed until the exceptions narrow to the extent that they cease to exist. Although the law on sexual orientation discrimination provides some recognition of the need to balance that right against religious

154 Cardinal Cormac Murphy O'Connor, then head of the Roman Catholic Church in England and Wales, wrote to the Cabinet asking for an exception. However, whilst the then Prime Minister Tony Blair was reportedly in favour of an exception, he was outmanoeuvred by his Cabinet colleagues.

155 Regulation 15 of the 2007 Regulations provided an exception that ran until 31 December 2008.

156 The litigation concerned the exception found within Regulation 18 of the 2007 Regulations which allows charities to discriminate on ground of sexual orientation if it is 'in pursuance of a charitable instrument'. Catholic Care sought the consent of the Charity Commission to change their charitable object so that they could enjoy this exception. In Catholic Care (Diocese of Leeds) $v$ Charity Commission for England and Wales [2009] Charity Tribunal CA/2008/0003 (1 June 2009), the Charity Tribunal refused to give consent to this. The matter then went to the High Court ([2010] EWHC 520), where Briggs J concluded that the Charity Tribunal's interpretation of reg 18 of the 2007 Regulations was incorrect and directed that the question be remitted to the Charity Commission to decide 'directing itself in la in accordance with the principles set out in this judgment (para 111). The Charity Commission duly reconsidered the matter; again rejecting Catholic Care' attempt to change its Governing Document ([2010] Ch Comm E \& W final determination (21 July 2010)). At time of writing, a further appeal to the Upper Tribunal is awaited.

157 The Coalition Government has no plans to change this. See the comments of Baroness Neville-Jones: 'We are certainly committed to ... allowing people such freedom to hold religious beliefs. However, we have [to] strike the right balance and sure that we do not allow discrimination on any grounds. When it comes to offering public services, the law of the land must be obeyed ': HL Deb 8 July 2010 c 336.

158 Para $2(7)-(9)$. 
freedom, ${ }^{159}$ cases on the scope of the exception are likely to follow Ladele $v$ London Borough of Islington ${ }^{160}$ and McFarlane v Relate Avon $\operatorname{Ltd}^{161}$ : the laudable need to eliminate discrimination on grounds of sexual orientation is likely to trump the equally laudable need to prevent discrimination on grounds of religion or belief.

\section{CONCLUSIONS}

The Coalition Government's new Equality Strategy, published in December 2010, makes little reference to issues concerning sexual orientation or religion. Indeed, it talks of 'the Government's new approach to tackling inequality: one that moves away from treating people as groups or "equality strands" and instead recognises that we are a nation of 62 million individuals' and pointedly remarks 'new legislation and increased regulation has produced diminishing returns' ${ }^{162}$ Further major legislative activity therefore looks unlikely in the short term. This may not be a bad thing. The legal changes examined in this article need time to bed in. However, the case law to date in a range of different areas does point to a growing concern. Whilst the much-heralded laws on sexual orientation seem to have made significant and welcome improvements, the same cannot be said in relation to religious freedom. Laws protecting religious freedom have had little effect, ${ }^{163}$ while laws protecting sexual orientation seem to have constrained religious freedom.

The opening decade of the 21st century has seen a substantial shift in the way in which the law protects religion and sexual orientation. A passive stance of toleration has been superseded by the active promotion of religious freedom and equality on grounds of sexual orientation as positive basic rights. Although there were important precursors to the four legal developments discussed, the four collectively may be said to mark a step change.

Even before the Human Rights Act 1998, but especially so after it, the rights expressed in the ECHR have provided a basic standard for the law in the terms of individual rights that need to be balanced. The Human Rights Act 1998 may be seen as the base of the new law on sexual orientation and, to a lesser extent, the law on religion: many of the steps taken in the last decade would not have been taken were it not for the Convention in general and the Human Rights Act 1998 in particular. The Civil Partnership Act 2004 built upon this, representing a bold step forward in the recognition of same-sex couples. But the lack of conceptual

159 Compare the Civil Partnership Act 2004 (until s 202 of the Equality Act 2010 comes into force).

160 [2009] EWCA Civ 1357.

161 [2010] EWCA Civ 880.

162 HM Government, The Equality Strategy, pp 6-8.

163 See further Sandberg, Law and Religion, especially chapter 10. 
clarity at the heart of the Act has proved problematic and this would become even more problematic if the template of civil marriage is jettisoned.

The new offences of stirring up hatred on grounds of religion and sexual orientation are not only based upon the assumption that the law can deal with these forms of identity in the same way but are also based on the assumption that toothless, ambiguous and largely symbolic criminal offences are helpful. The laws prohibiting discrimination on grounds of religion and sexual orientation have led to an abundance of claims and have brought forward cases where the two equality streams clash. The early skirmishes suggest that employers' concerns about promoting equality on grounds of sexual orientation will trump employees' concerns about their right not to be discriminated on grounds of religion or belief. A similar picture can be seen in the long-running debates about religious exceptions which allow discrimination on grounds of sexual orientation. One of the few things that is clear about the religious exceptions, now found in the Equality Act 2010, is that they are intended to be narrow, but probably not as narrow as the proposed (and rejected) changes in earlier versions of the Bill would have made them.

In sum, during the last decade passive accommodation has been replaced by prescriptive regulation. In some respects, this is clearly a very good thing. It would be difficult to disagree with the assessment found in the Coalition Government's new Equality Strategy that Britain has 'come a long way' and is now 'a more diverse and tolerant country'. ${ }^{164}$ However, at the very least, the pace of change and the complicated overregulation presents a multifaceted picture. In particular, it is noticeable that the growth of the law on sexual orientation is somewhat faster than the growth of the law protecting religion. The right for religious groups and individuals to discriminate on grounds of sexual orientation is narrow and is increasingly reducing. Thus the precise delineation of its reach is of importance not merely to academics and jurists, but to the population at large. 